\title{
Myślenie strategiczne o pracowniku - możliwość czy potrzeba współczesnej organizacji?
}

Nadesłany: 20.09.12 | Zaakceptowany do druku: 16.10.12

\section{Anna Pluta ${ }^{1}$}

\section{Abstrakt}

Cel: Autorka podejmuje problem podejścia do pracownika przez organizację. Celem artykułu jest znalezienie odpowiedzi na pytanie: „Czy myślenie strategiczne o pracowniku jest możliwością, czy potrzebą współczesnej organizacji?".

Metodologia: Podstawę do prowadzonych w artykule rozważań stanowią studia literaturowe. Na ich kanwie wysuwane są wnioski, których potwierdzenie stanowią prezentowane wybrane wyniki badań empirycznych przeprowadzonych przez krajowe i międzynarodowe ośrodki badawcze.

Wyniki: Zaprezentowane rozważania wskazują, że współczesne organizacje muszą myśleć strategicznie o pracowniku, jeśli chcą odnosić sukcesy. Jednak myślenie to nie może ograniczać się do inwestowania w kompetencje kadry; musi również obejmować budowanie środowiska zapewniającego sukces organizacji i pracownika.

Oryginalność: Autorka wskazuje na konieczność strategicznego podejścia do pracownika we współczesnym świecie biznesu. Jednocześnie pokazuje, że organizacja nie może myśleć o pracowniku tylko z punktu widzenia własnego zysku. W myśleniu strategicznym o pracowniku musi być również miejsce na zysk - sukces pracownika. Słowa kluczowe: myślenie strategiczne; podejście do pracownika, relacje organizacja-pracownik

\section{Strategic thinking about employees - possibility or need of the contemporary organization?}

Primary submission: 20.09.12 | Final acceptance: 16.10.12

\begin{abstract}
Purpose: The article concerns the contemporary approach to employees in organizations, and the research question is whether strategic thinking about employees is a possibility or necessity of the contemporary organization. Methodology: Literature research was the basis for the deliberations and proposals, which were analyzed using several empirical studies conducted by Polish and international research centers.

Results: The presented discussion suggests that contemporary organizations should think strategically about their employees if they want to succeed. But this approach cannot be limited only to investing in employee competencies, but should also take into consideration building a working environment that ensures the success of both the organization and the worker.

Originality: The article suggests the necessity of a strategic approach regarding employees in the contemporary business world. At the same time it indicates that organizations cannot treat employees only with the organizational profits in mind. In strategic thinking about employees there must also be room for other benefits, such as the success of an employee.

Keywords: strategic thinking, approach to employees, organization-employee relationship
\end{abstract}

JEL: M12

\footnotetext{
1 Uniwersytet Szczeciński

Adres do korespondencji: Uniwersytet Szczeciński, Wydział Nauk Ekonomicznych i Zarządzania, ul. Mickiewicza 64, 71-101 Szczecin, e-mail: apluta@vp.pl.
} 


\section{Wprowadzenie}

Ulegające nieustannym przeobrażeniom warunki funkcjonowania współczesnych organizacji wymuszają zmiany w sposobach zarządzania nimi. W coraz większym stopniu doceniany jest człowiek - pracownik, gdyż od jego postawy, zachowania i efektów pracy uzależniona jest konkurencyjność organizacji. To właśnie on jest nośnikiem wiedzy, będącej kluczowym warunkiem przetrwania i rozwoju organizacji w burzliwym i nieprzewidywalnym otoczeniu. Zatem w proces zarządzania włączane są rozważania dotyczące ludzi i posiadanego przez nich kapitału oraz konstruowane są propozycje konkretnych rozwiązań dotyczących pracowników w działaniach bieżących oraz strategicznych współczesnych organizacji.

O ile strategiczny wymiar potencjału ludzkiego stosunkowo łatwo zaadaptował się do praktyki organizacji i strategia personalna stanowi istotną część strategii organizacji, o tyle niepokojący wydaje się fakt nieco przedmiotowego traktowania pracownika w procesie określania i implementacji strategii potencjału społecznego. Dość często dążące do sukcesu rynkowego organizacje są postrzegane przez kadry nimi zarządzające raczej jednowymiarowo, jako podmioty gospodarcze, co powoduje, że ich strategie są nastawione na wyniki, ponieważ przeżycie i pomyślność są uzależnione od „dostarczania najwyższej wartości na wymagającym, niewybaczającym błędów rynku globalnym” (Eisenstat i in. 2008, s. 131). Oczywiście prawdą jest, że wyniki finansowe są istotne w działalności gospodarczej i istnienie organizacji niegenerującej zysku nie ma sensu. Jednak przyjęcie tylko tego punktu widzenia prowadzi do realizowania procesu zarządzania skoncentrowanego wyłącznie na interesach właścicieli, udziałowców - sukcesu finansowego. Taka determinacja do osiągania wyłącznie wyniku finansowego może wywoływać rozczarowanie pracowników oraz prowadzić do spadku ich lojalności i zaangażowania w kształtowanie wartości organizacji.

Dlatego ważne jest uwzględnianie w procesie zarządzania drugiego wymiaru organizacji - instytucji społecznej, która oddziałuje na życie pracowników, nieraz w ogromnym stopniu (ibid., 131 i nast.). Tym samym w strategii istotna jest konieczność stałego zwiększania wydajności pracy, by móc wypracowywać określone zyski, na których zależy właścicielom i udziałowcom, ale również dbanie o dobro i interesy pracowników, by wyzwolić ich energię i skierować ją na realizację przyjętych założeń strategicznych. To przecież ludzie zatrudnieni w organizacji swoją pracą przyczyniają się do określenia i utrzymania jej pozycji na rynku, osiąganych wyników - teraz i w przyszłości. Dlatego tylko godzenie obu wymiarów funkcjonowania organizacji i jednoczesne uwzględnianie w strategii działania pozwala zbudować stabilną instytucję odnosząca sukcesy w aspekcie finansowym i ludzkim.

Gdy weźmie się to pod uwagę, istotne wydaje się poszukiwanie sposobów pozwalających rozwiązać występujący w wielu współczesnych organizacjach konflikt na linii sukces finansowy-ludzie. Teoretycznie pogodzenie obu stron sprowadza się do wypracowania równowagi w dążeniu do osiągania celów organizacyjnych mierzonych wynikami finansowymi i trosce o interesy pracowników. Praktyka pokazuje jednak, że uzyskanie takiego stanu nie jest proste 
i wiele organizacji ma z tym problem. Jakie są powody tej sytuacji i wynikające z tego konsekwencje?

\section{| Podmiotowe podejście do pracownika w organizacji}

Przyznanie pracownikowi najważniejszej roli w generowaniu zysku organizacji zmienia, a przynajmniej powinno modyfikować podejście do kadry pracowniczej. Bez zaangażowanych ludzi realizujących stawiane przed nimi zadania niemożliwe jest osiąganie sukcesów przez organizację w perspektywie krótko- i długofalowej. Oznacza to, że sukces nie powinien być rozpatrywany wyłącznie w aspekcie finansowym, ale również ludzkim. Takie podejście umożliwia organizacji realizację opracowanych założeń strategicznych, jak również daje możliwość osiągania celów indywidualnych poszczególnych pracowników. Tym samym tak popularna dziś w teorii zarządzania koncepcja wygrany-wygrany musi mieć swoje odzwierciedlenie w relacjach organizacja - pracownik. Dopiero współzależność w osiąganiu sukcesu ukazuje pracownika jako partnera w działalności biznesowej.

Wspólnota interesów na linii organizacja-pracownik powoduje, że zasoby ludzkie należy traktować w organizacji w szczególny sposób. Nie mogą one być jeszcze jednym środkiem nietrwałym, ponieważ pracownicy są zasobem, który czuje i reaguje. Są oni zatem podmiotem, a nie przedmiotem w organizacji, a to nadaje nowy sens słowu „sukces”. Nie jest ono interpretowane wąsko jako zwycięstwo, wygrana czy osiągnięcie celu, co można spotkać w popularnych ujęciach. Ich cechą wspólną jest rozumienie sukcesu jako jednorazowego efektu i to, co dziś stanowi sukces, za chwilę może nim nie być. Okazuje się, że patrząc szerzej, można zdefiniować sukces jako proces, postawę, podejście do życia danej osoby, ale i organizacji. Sukces można więc opisać jako działanie na najwyższym poziomie swoich możliwości, zgodne z własnymi, w pełni uświadomionymi pragnieniami z zachowaniem kodeksu moralnego oraz równowagi pomiędzy wszystkimi obszarami życia (Majewska-Opiełka, 2003, s. 25). Tak pojmowany sukces jest drogą dwukierunkową, autentyczną, permanentną i trwającą przez całe życie człowieka czy organizacji. Nie jest uzależniony od przypadku, szczęśliwego trafu, ale stanowi dążenie do wielkości, opierając się „dawaniu” i „braniu” w atmosferze wzajemnego zaufania, współpracy i odpowiedzialności (Waitley, 1996, s. 52).

Osiąganie tak interpretowanego sukcesu nakłada na organizację wiele obowiązków, wśród których szczególne znaczenie ma uczciwe postępowanie. W dobie gospodarki opartej na wiedzy organizacje są coraz bardziej uzależnione od zaangażowania i kreatywności swoich pracowników, a to powoduje, że kwestia uczciwego podejścia jest bardzo ważna. Brak troski o uczciwy charakter procesów realizowanych w organizacji może przyczyniać się do wielu problemów z osiąganiem założonych celów, ponieważ wpływa na postawy, nastawienie i zachowanie pracowników. Okazuje się bowiem, że ludziom nie tylko zależy na efekcie końcowym działania, ale mają również na uwadze procesy, które do określonego skutku prowadzą (Kim i Mauborgne, 2006, s. 183). O ile pierwsze założenie, że rezultaty są ważne, jest znane i wykorzystywane w teo- 
rii i praktyce zarządzania, o tyle drugie, odnoszące się do sposobu ich osiągania, w wielu organizacjach jest lekceważone i pomijane. Niestety organizacja często zdaje sobie sprawę z popełnionego błędu dopiero w wyniku skarg i protestów pracowników, czyli w znacznym stopniu za późno (ibid., 190).

A przecież strategia tworzenia uczciwych relacji pomiędzy organizacją a pracownikiem nie jest trudna do opracowania i powinna stanowić element budowania lojalności wszystkich grup interesariuszy organizacji. Trudno bowiem liczyć na lojalność klientów, dostawców, udziałowców, jeżeli organizacja nie dysponuje lojalnymi pracownikami.

Budowanie lojalności pracowników umacnia pozytywną relację na linii organizacja-pracownik, przez co wzbudza zaufanie, nadzieję i zaangażowanie oraz stanowi podstawę do dobrowolnej współpracy między pracownikami. Dodatkowo uczciwość organizacji oddziałuje pozytywnie na poczucie wartości pracownika, co przekłada się na jego pewność siebie w pracy, świadomość tożsamości, odwagę i kreatywność. Należy również zaznaczyć, że budowanie poczucia własnej wartości wśród pracowników odgrywa znaczącą rolę w kształtowaniu wewnętrznej motywacji pracowników i ich postawy wobec pracy (Pierce i Gardner 2004: 591-622) oraz odsuwa niebezpieczeństwo wystąpienia u nich syndromu neurotycznego impostora, który może być szkodliwy zarówno dla pracownika, jak i organizacji go zatrudniającej (Kets de Vries, 2006, s. 106-114).

W kontekście dotychczasowych rozważań nie dziwi fakt, że organizacja musi zaakceptować prawdę, iż zysk to nie wszystko. Liczy się pracownik i jego praca, ambicje, zainteresowania oraz potrzeby, ponieważ od tego uzależniony jest wynik organizacji. A skoro tak, to należy go traktować jako osobę aktywnie uczestniczącą w działalności organizacji i wykazywać troskę o jego samopoczucie w pracy, zadowolenie z realizowanych zadań, zaspokojenie potrzeb życiowych.

\section{| Diagnoza współczesnego podejścia do pracownika}

Świat biznesu otrzymał w ostatnich latach dość bolesną lekcję, że patrzenie na organizację tylko przez pryzmat jednowymiarowy podmiotu gospodarczego prowadzi do chciwości. Zachłanność w biznesie nie jest receptą na sukces, ponieważ „wynik, który mechanicznie wyliczają systemy księgowe, tworzą nie bezduszne cyferki, ale żywi ludzie” (Krawiec, 2011, s. 26). Okazuje się jednak, że nie wszystkie organizacje dokonały rewizji swojego procesu zarządzania i wprowadziły odpowiednie modyfikacje zmieniające podejście do zatrudnionej kadry. Funkcjonowanie w świecie wszechobecnej konsumpcji i materializmu powoduje, że w organizacjach najbardziej liczą się zyski, zwrot z aktywów lub wartość dodana. Pieniądz jest podstawowym, a często jedynym, miernikiem sukcesu (wąsko rozumianego) oraz racjonalności podejmowanych decyzji, a to z kolei sprawia, że „każda aktywność ludzka jest wyceniana i zamienia się w towar, a wszystkie oceny wartościujące zastępuje pytanie: ile?” (Aitkenhead, 2012, s. 26). Oznacza to, że ceny rynkowe zastępują wartości moralne i uzurpują sobie prawo do oceny wartości wszystkiego i wszystkich ze względu na swój obiektywizm i neutralność. Jednak o ile sprawdza się taka ewa- 
luacja w odniesieniu do rzeczy materialnych, o tyle nie można tej miary zastosować do oceny człowieka, jego wiedzy czy godności. Człowiek będący pracownikiem organizacji, jak również wykonywane przez niego zadania prowadzące do realizacji przyjętych założeń strategicznych nie mogą podlegać prostym, bezwzględnym ocenom rynkowym, ponieważ one nie pokazują wszystkiego, co cenne (tego, co tkwi w głowie danego człowieka i pobudza go do określonego działania, czyli przymiotów bardziej delikatnej natury, na ogół trudnych do zmierzenia) i nie przechodzą tzw. próby lustra - sprawdzianu wartości etycznych (Drucker, 2006, s. 39) (ostatnie zawirowania w sektorze parabanków dają wyraźny przykład, że wyceny rynkowe nie mogą dominować w ocenie).

Oparcie relacji organizacja-pracownik na wycenie pieniężnej zamienia człowieka w towar i powoduje powrót do niewolnictwa, jednak w nowej, uwspółcześnionej odsłonie. Nie jest to bowiem niewolnictwo będące zjawiskiem społecznym, w którym pewna grupa ludzi stanowi własność innej (choć i takie przykłady można znaleźć w dzisiejszym świecie), ale raczej niewolnictwo wynikające z całkowitego podporządkowania się komuś lub czemuś (Słownik języka polskiego 2012). Pracownik przestaje wtedy być osobą zasługującą na szacunek i godność, zostaje sprowadzony do przedmiotu do wykorzystania, instrumentu pozwalającego na osiąganie zysku. Organizacja korzysta z takiego narzędzia dopóty, dopóki zapewnia jej korzyści finansowe, a jeśli ich nie uzyskuje, to zastępuje je „nowym modelem” - jednego pracownika zwalnia, a na jego miejsce zatrudnia nowego. Ta smutna prawda znajduje odzwierciedlenie w wielu współczesnych organizacjach realizujących politykę personalną zgodną z podejściem sita, które opiera się na rywalizacji i konkurencji między pracownikami (Król, Ludwiczyński, 2006, s. 80). W efekcie takiego postępowania organizacji zatrudnieni w niej pracownicy stają do bezsensownej gonitwy nazywanej potocznie „wyścigiem szczurów”, poświęcają się pracy i dążą po trupach do celu.

Okazuje się, że uwolnienie się z „wyścigu szczurów” nie jest łatwe. Wśród powodów utrudniających wyrwanie się z bezwzględnej rywalizacji zawodowej można wymienić m.in.:

- zauważalny etos pracy i traktowanie jej jako warunku osiągania sukcesów w życiu (CBOS 2011: 6);

- przekonanie, że praca to przede wszystkim sposób na zdobycie pieniędzy (CBOS 2011: 7), który daje utrzymanie i pozwala zaspokajać własne potrzeby bytowe, jak również potrzeby członków rodziny pracownika;

- przekonanie, że praca zapewnia korzyści materialne - możliwość nabywania i gromadzenia dóbr, co w czasach konsumpcyjnego stylu życia i upowszechnienia się schematów życia opartych na posiadaniu jest bardzo ważne;

- przekonanie, że praca i wynikająca z niej możliwość dysponowania określonymi dobrami pozwalają na dokonanie oceny siebie i innych, a przez to odzwierciedlają materialną przewagę nad innymi ludźmi i decydują o pozycji osiąganej w hierarchii społecznej (Veblen, 1971), stanowią wyznacznik statusu i prestiżu (Merrill i Merrill, 2004, s. 179-180);

- zmienność trendów i sezonowe mody wpływające na modyfikacje stylu życia oraz wyrażających go standardów, co pociąga za sobą konieczność nabywania nowych dóbr, a to z kolei 
wymusza dalszą pracę, która pozwoli na ich zakup. Zjawisko takie sprzyja rozwojowi tzw. konsumpcji gadżetowej (Plażyk, 2011, s. 991).

Nie bez znaczenia jest również fakt, że zdaniem niektórych członków współczesnego społeczeństwa uczestnictwo w „wyścigu szczurów” nie ma w sobie nic nagannego, wręcz przeciwnie - jest tym, czego człowiek potrzebuje i co kocha, dzięki czemu może się rozwijać (Buchholz, 2011). Przyjęcie takiego punktu widzenia zmniejsza szansę na wyrwanie się z niewolnictwa pracy, ponieważ to właśnie praca jest przyjemnością, pozwala na osiąganie sukcesów, daje poczucie bycia potrzebnym i szanowanym, a próby oderwania się od pracy prowadzą do zmęczenia i irytacji (Kaniewska, 2012, s. 54). Taki człowiek godzi się na przedmiotowe podejście organizacji do niego i uprawomocnia tym samym realizację sukcesu organizacji na drodze jednokierunkowej w myśl koncepcji wygrany-przegrany, zapominając, że w tej sytuacji wygrywa tylko organizacja, a przegrywa on. Nawet jeśli zdaje sobie sprawę z nierówności relacji na linii organizacja-pracownik, traktuje je jako typowe w nowoczesnym świecie i nie zauważa w tym niczego złego, gdyż jest zafascynowany wykonywaną pracą oraz zadowolony z obranego stylu życia. Szuka przyjemności i znajduje ją właśnie w pracy, bo przecież człowiek zawsze robi to, co jego zdaniem przynosi mu zadowolenie. Poświęca większą ilość czasu i wysiłku na wykonywanie działań sprawiających mu największą przyjemność, a mniej czasu i wysiłku na aktywności sprawiające ból czy odbierane jako nieprzyjemne (Ringer, 1977, s. 10). Należy jednak zaznaczyć, że przekroczenie granicy pomiędzy pracą sprawiającą przyjemność i pozwalająca na zaspokojenie różnych potrzeb a pracą będącą katorgą, przymusem (wewnętrznym lub zewnętrznym), zniewalającą, jest czasami trudne do uchwycenia i niewidoczne dla człowieka ją wykonującego. Tymczasem zauważa to jego otoczenie - rodzina, przyjaciele i znajomi.

Ważne wydaje się zatem rozważenie sygnałów takiego „umiłowania” pracy, które może prowadzić do zniewolenia, zwłaszcza że konsekwencje ich przeoczenia nie tylko mogą być katastrofalne dla danego pracownika, ale również negatywnie wpływają na funkcjonowanie organizacji.

\section{| Konsekwencje przedmiotowego podejścia do pracownika}

Analizując skutki poświęcania się pracy będącej efektem przedmiotowego podejścia organizacji do pracownika, najczęściej wspomina się o stresie, który jest jednocześnie jedną z konsekwencji funkcjonowania w nowoczesnej, pełnej wyzwań rzeczywistości. Coraz częściej pojawiają się doniesienia o rosnących wskaźnikach nieobecności w pracy i niezdolności do wykonywania obowiązków zawodowych spowodowane stresem, a także informacje o wzroście kosztów walki ze skutkami stresu. Ze względu na to, że podobna sytuacja ma miejsce w wielu krajach, „Światowa Organizacja Zdrowia (WHO) uznała stres zawodowy za jedno z największych niebezpieczeństw XXI wieku" (Dettmer, Shafy, Tietz, 2011, s. 56-57). Natomiast wyniki badań firmy Extended Disc pokazują, że Polacy należą do najbardziej zestresowanych pracowników w Europie (Rzeczpospolita 2009). 
Wprawdzie stres ma pozytywne aspekty, ponieważ mobilizuje do uczenia się, podejmowania nowych wyzwań, zdobywania nowych doświadczeń w świecie, który zmienia się bardzo szybko, a przez to stwarza kolejne szanse na realizację określonych celów, jednak we współczesnym świecie decyzje trzeba podejmować szybko, szybko pracować, szybko się uczyć, szybko spać, szybko odpoczywać - działać w nieustannym przyspieszeniu, ponieważ zwolnienie tempa może spowodować, że pojawiająca się możliwość przeminie i nie będzie można osiągnąć sukcesu (oczywiście rozumianego wąsko). Przeciążenie i związany z nim stres zaczynają więc dominować i... pojawiają się problemy wynikające z „odrytmizowania” (Gut, 2008, s. 51). Człowiek gubi rytm dnia i nocy, obowiązujących pór roku, ponieważ praca zajmuje wiele godzin i kończy się późno w nocy. Dni - podobne do siebie - zaczynają się zlewać ze sobą, do tego dochodzi zaburzony czas posiłków, człowiek zaczyna dopasowywać pory posiłków do pracy, a czasami, by „podgonić zadanie”, zupełnie z nich rezygnuje. Efekt takiego postępowania to wiele zagrożeń cywilizacyjnych, wśród których najczęściej wymienia się: depresję, pracoholizm, wypalenie zawodowe, cukrzycę, alergie, nałogi - wyniszczające organizm i powodujące kryzysy w relacjach międzyludzkich.

Należy jednak jasno zaznaczyć, że mechanizm stresu jest człowiekowi potrzebny. To właśnie on, między innymi, doprowadził do rozwoju ludzkości. Poza tym pewna dawka presji psychicznej pozwala dostosować zachowanie do wymagań zmieniającego się świata. Jednakże współczesny człowiek nieustannie uczestniczy w sytuacjach stresujących, nie może się od nich uwolnić czy ich przetworzyć, gromadzi w sobie negatywną energię stresu w postaci hamowanej agresji czy lęków. W efekcie doprowadza organizm na skraj wyczerpania, co może wywołać różne choroby, a nawet śmierć. Z tego powodu długo utrzymujący się stres w pracy powinien stanowić sygnał do zmian, ponieważ wystąpił „,brak równowagi między obciążeniami i zasobami”, które posiada człowiek (ibid., s. 56). Jeśli sygnał ten zostanie zlekceważony, to wewnętrzne rezerwy człowieka będą się wyczerpywać i zacznie on tracić siły.

Negatywną konsekwencją pracy w stresie może być pracoholizm stanowiący obecnie jeden z najgroźniejszych nałogów człowieka, do tego cieszący się olbrzymim poszanowaniem (Kilinger, 2007, s. 20). Pracoholizm wiąże się z nadmiernym uzależnieniem od pracy, która staje się stanem umysłu, zaczyna dominować w życiu pracoholika, stanowiąc ucieczkę od prywatności i związanej z nią odpowiedzialności za innych ludzi. Człowiek uzależniony od aktywności zawodowej wręcz obsesyjnie koncentruje wszystkie swoje myśli na pracy. Realizacja zadań zawodowych staje się wewnętrznym neurotycznym przymusem i koniecznością uwalniającą od negatywnych emocji, a to powoduje, że coraz więcej czasu poświęca pracy. Znoszone są „granice pracy” (Dettmer i in., 2011, s. 58), przez co pracownik nabiera poczucia, że musi być zawsze dyspozycyjny, na każde wezwanie firmy przez 24 godziny na dobę, w każdy dzień roku.

Wśród cech lub objawów pracoholizmu wymienia się (Wojdyło, 2010): doświadczanie stałych stanów napięcia; stawianie sobie coraz wyższych standardów wykonania zadań, podejmowanie coraz większej liczby zadań i poświęcanie im coraz dłuższego czasu; poczucie przymusu pracy; utrata kontroli nad pracą; praca daje poczucie ulgi; niemożność powstrzymania się od pracy; 
nieustanne myślenie o pracy; uporczywa kontynuacja podjętych działań zawodowych pomimo świadomości ich negatywnego wpływu na własny organizm i relacje społeczne. Dostrzeżenie trzech lub więcej z wymienionych cech w ciągu roku pozwala rozpoznać problem pracoholizmu (ibid.).

Jak wykazują badania (Wojdyło, 2012, s. 62), Polacy są świadomi problemu pracoholizmu, jego konsekwencji i potrafią go rozpoznać. Aż 46\% respondentów (zarówno kobiety, jak i mężczyźni) deklaruje podjęcie terapii po otrzymaniu sugestii od kogoś bliskiego, że są pracoholikami. Czy faktycznie to zrobią, wydaje się dyskusyjne ze względu na fakt, że pracoholicy niejednokrotnie zaprzeczają temu, iż są pracoholikami i „często myślą o sobie jako o pasjonatach pracy” (ibid., s. 61). Być może powód tkwi w tym, że pracoholizm nie jest stanem jednorodnym, ale ma trzy oblicza (Sasak, 2004, s. 4):

- napadowy, sporadyczny - występuje najczęściej w „sytuacjach awaryjnych”, „za pięć dwunasta”;

- cykliczny - praca zawodowa podlega cyklicznym metamorfozom - naprzemiennie występują okresy wytężonej, intensywnej pracy, a po nich następuje okres względnego spokoju, a czasami nawet monotonii i nudy;

- permanentny - najbardziej szkodliwy dla człowieka, ponieważ uzależnienie od pracy jest już chroniczne.

Badania nad zjawiskiem pracoholizmu pokazują, że człowiek będący permanentnym pracoholikiem przez okres trzech lat ulega wypaleniu zawodowemu i jego efektywność pracy spada o około 60\% w porównaniu z efektywnością z okresu rozpoczęcia pracy (ibid.: 2). Powodem tego jest spadek motywacji do dalszego działania z uwagi na psychiczne, emocjonalne oraz fizyczne wyczerpanie, brak satysfakcji z wykonywanej pracy i towarzyszące jej złe samopoczucie, osłabnięcie energii i entuzjazmu oraz kształtowanie się dysfunkcyjnych zachowań i postaw w pracy. Taka erozja duszy rozwija się stopniowo i często dotknięty nią człowiek nie zdaje sobie z tego sprawy przez dłuższy czas (Schaufeli i Enzmann, 1998, s. 36). Okazuje się również, że pracownicy, którzy czują, że się wypalili, nie mówią o tym, ponieważ wstydzą się tego i jednocześnie boją się, że stracą pracę. Z tych powodów dość trudno określić, ilu Polaków jest dotkniętych wypaleniem zawodowym. Jednak biorąc pod uwagę, że w USA jest to połowa pracujących Amerykanów, można przypuszczać, że i w Polsce ich odsetek jest niemały (Wrabec, 2009, s. 51).

Źródłem wypalenia jest brak dopasowania pomiędzy pracownikiem i realizowaną przez niego pracą (Maslach i Leiter, 2011, s. 41-58). Badania nad syndromem wypalenia zawodowego wykazują, że istnieje sześć obszarów pracy, które należy uwzględniać w ocenie jego ryzyka, do których należą (ibid., s. 26-34 i 44-45): nadmierne obciążenie pracą, brak kontroli, brak nagrody, załamanie wspólnoty, brak sprawiedliwości, konflikt wartości.

Wypalić może się każdy, a to, czy pracownik się wypali, zależy w większym stopniu od środowiska pracy niż cech danej osoby (ibid: 35-40). Praca w organizacji pozwala na zaspokajanie różnych potrzeb człowieka. Świadomość tego pobudza do działania i wywołuje zaangażowanie 
w pracę. Jednak środowisko pracy, w którym funkcjonuje człowiek, może doprowadzić do jego wypalenia, a wtedy wcześniejsza energia, oddanie i skuteczność zostają wyparte przez wyczerpanie, cynizm i nieskuteczność (rysunek 1).

\section{Rysunek 1 | Erozja zaangażowania}

\section{ZAANGAŻOWANIE W PRACE}
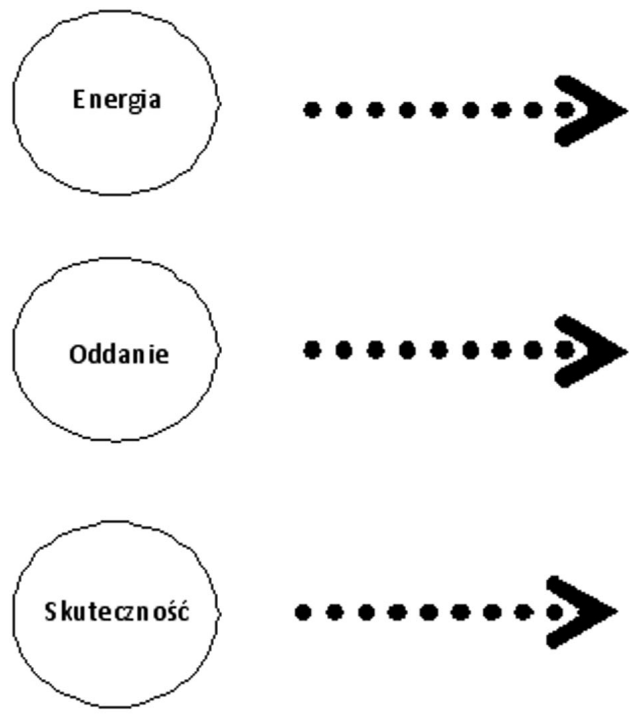

\section{WYPALENIE ZAWODOWE}
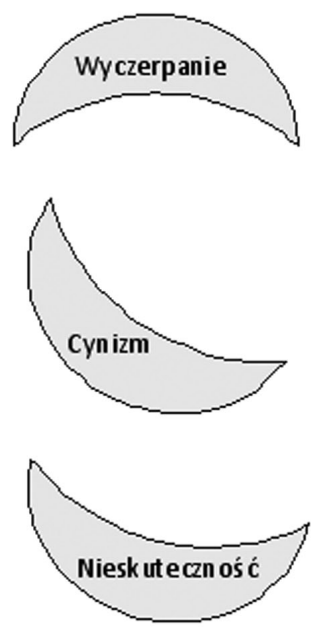

Źródło: Chrzanowska (2012, s. 72).

Dehumanizacja środowiska pracy może zatem mieć trzy wymiary (ibid., s. 34-35):

- Wyczerpanie emocjonalne - wywołane jest brakiem energii potrzebnej do realizacji zadań zawodowych i stanowi pierwszą reakcję na stres występujący w sytuacji nadmiernego obciążenia emocjonalnego i fizycznego. W efekcie człowiek czuje się zmęczony, wyczerpany i niezdolny do odprężenia i odzyskania zużytej energii.

- Cynizm i depersonalizacja - występują, gdy wcześniejsze oddanie się pracy jest zastępowane przyjęciem wobec niej chłodnej postawy i zdystansowaniem wobec współpracowników; uwidacznia się spadek zaangażowania w pracę oraz porzucenie ideałów, a praca zatraca sens. Cynizm jest próbą ochrony przed rozczarowaniem i wyczerpaniem.

- Brak skuteczności - dominuje tutaj negatywna ocena siebie, odczuwa się narastające poczucie niedopasowania i każde nowe zadanie zdaje się przerastać pracownika. To powoduje w nim utratę wiary we własne możliwości, a także wywołuje spadek zaufania otoczenia do niego.

Brak reakcji organizacji na wypalenie zawodowe jej pracowników może być przyczyną depresji. Jak wykazują badania, jeśli erozja duszy danej osoby trwa przez 5 lat, to aż o 70\% wzrasta ryzyko 
depresji (Dettmer i in., 2011, s. 58). Fakt ten oraz to, że stres, pracoholizm i wypalenie mogą prowadzić do wielu chorób, powoduje, że organizacje powinny solidnie zrewidować swoje podejście do pracowników i w większym stopniu o nich zadbać.

\section{Kierunki poprawy sytuacji pracownika w organizacji}

Realizowane we współczesnych organizacjach programy zarządzania zasobami ludzkimi wymagają restrukturyzacji. Ostatnio wiele polskich organizacji doskonaliło wiedzę i umiejętności swoich pracowników, korzystając z dofinansowania UE. Jednak nie ma sensu inwestowanie w ludzi, podczas gdy ich środowisko pracy uniemożliwia im wykorzystanie w pracy maksymalnych możliwości. Takie działania tylko podnoszą koszty działalności, a nie prowadzą do wzrostu zysku ze względu na niską skuteczność pracowników oraz wydajność ich pracy. Według ostatnich danych OECD Polacy nie należą do wydajnych pracowników (OECD 2012). W 2011 roku wydajność polskiego pracownika była oceniana na poziomie 26,2 PKB na przepracowaną godzinę (w USD). Wynik ten jest dość słaby w porównaniu z przodującą w tym rankingu Norwegią, gdzie wydajność pracownika jest oceniana na poziomie 81,5 PKB na przepracowaną godzinę (w USD). W kontekście danych OECD gorsza wydajność dotyczy tylko pracowników: Estonii, Rosji, Chile i Meksyku.

Zaprezentowane dane potwierdzają potrzebę wprowadzenia zmian w podejściu do pracownika w organizacji. Ważny jest nacisk na zwiększanie wydajności, ale nie można go wiązać z dalszym zwiększaniem liczby zadań do wykonania, a także z przedłużaniem czasu pracy [Polacy są w ścisłej czołówce najbardziej zapracowanych narodów! (OECD 2012)]. Te sposoby okazały się, jak do tej pory, nieskuteczne i przyszłość też nie jest przychylnie do nich nastawiona. Na rynek pracy wchodzi nowe pokolenie - Generacja Y. Dotychczasowe podejście do pracownika praktykowane przez organizacje już na starcie jest skazane na porażkę.

Generacja Y, wychowana w cyfrowym świecie, wykazuje podejście do życia odmienne niż wcześniejsze pokolenia (np.: Młodzi 2011: 35-64; Fazlagić, 2008; Grzybek, 2012, s. 20-26). Ludzie ci są pozytywnie nastawieni do pracy, poprzez aktywność zawodową pragną się realizować i rozwijać, ale nie chcą, aby praca zdominowała ich życie. Potrzebują pracy, cenią jednak też inne działania, które nie są z nią związane, ponieważ chcą w pełni korzystać z możliwości, jakie stwarza współczesny świat i po prostu cieszyć się życiem. Doceniają pozytywny klimat pracy i odstrasza ich atmosfera podejrzliwości oraz rywalizacji charakterystyczna dla „wyścigu szczurów”.

Biorąc to pod uwagę, współczesna organizacja musi nie tylko zmienić podejście do pracownika, ale też zmodyfikować sposób myślenia o nim. Już nie wystarcza bieżące dostosowywanie się do pojawiających się trendów i dostrzeganych zagrożeń oraz możliwości. Leczenie nigdy nie było, a w dzisiejszych czasach na pewno nie jest, najlepszą strategią działania (jest kosztowne, długotrwałe i niestety nie zawsze w pełni skuteczne), zdecydowanie lepsza jest profilaktyka. Ona jednak wymaga wcześniejszego przygotowania: diagnozy sytuacji, wniosków, określenia kierunków 
działania. Dlatego współczesna organizacja musi myśleć o pracowniku z dwóch perspektyw: „tu i teraz” oraz „przyszłości”. Oznacza to, że nie tracąc z pola widzenia dzisiejszych pracowników i ich sytuacji, należy myśleć „do przodu” i przygotowywać się na nowych pracowników oraz ich oczekiwania. Takie możliwości stwarza myślenie strategiczne o pracowniku. Dzięki temu organizacja jest zdolna sterować rozwojem zasobów ludzkich w sposób przemyślany i zaplanowany, doskonalić środowisko ich pracy zarówno fizyczne, jak i społeczne w sposób umożliwiający kreowanie lepszej przyszłości pracowników w organizacji. Działanie takie pozwala również osiągać sukces w myśl koncepcji wygrany-wygrany przez organizację i zatrudnionych w niej pracowników.

Oczywiście można stwierdzić, że współczesne organizacje już teraz myślą strategicznie o pracowniku, ponieważ opracowują strategie personalne. Jednak strategie te każą patrzeć na pracownika pod kątem zysków, które może przynieść on i jego praca teraz i w przyszłości. Zawierają rozbudowane ścieżki kariery, programy szkoleń, pakiety motywacyjne, z pewnością oparte na wcześniejszej analizie potrzeb i oczekiwań pracowników, co nie zmienia faktu, że strategie te mają jeden i tylko jeden cel - zysk organizacji, i z tego punktu widzenia są opracowywane. Człowiek nie jest w nich celem, lecz jedynie środkiem do osiągnięcia wyniku finansowego, co powoduje, że przestaje być istotą ludzką i funkcjonuje jako istota pracująca (Fromm, 2011, s. 218).

Czy można to zmienić? Tak, ale wymaga to strategicznego myślenia o człowieku jako istocie żywej, myślącej, mającej potrzeby, marzenia, pasje i dążenia. Takie myślenie pozwala doskonalić organizację, by mogła być bardziej „ludzka”, a przynajmniej przyjazna ludziom i nieszkodząca im. Dzięki temu organizacja staje się atrakcyjnym miejscem pracy, nie ma problemów, gdy chce zatrudnić pracowników, nie boryka się z nieobecnością w pracy, nagłymi odejściami kadry itp. Aby taki stan osiągnąć, organizacja musi zadbać nie tylko o umysł pracownika, który tak bardzo się liczy w gospodarce opartej na wiedzy, ale również o jego ciało, emocje i ducha.

Jednym z rozwiązań tak określonego problemu wydaje się uwzględnienie w strategii organizacji, a zwłaszcza strategii personalnej, modelowania pracy (job sculpting) będącego sztuką „dopasowania ludzi do stanowiska w sposób umożliwiający ekspresję głębokich zamiłowań [...], zbudowania odpowiadającej potrzebom pracowników ścieżki kariery w celu zwiększenia szansy na zatrzymanie zdolnych ludzi” (Butler i Waldroop, 2006, s. 82). Przyjęcie takiej taktyki wymaga zindywidualizowanego działania obejmującego (ibid., s. 85-89):

- Identyfikację głęboko zakorzenionych w pracowniku zamiłowań. Okazuje się, że biorąc pod uwagę całą pracę w biznesie, można wyróżnić osiem typów działań, które mogą stanowić pasję. Znajdują się wśród nich: stosowanie technologii, analiza ilościowa, rozwój teorii i myślenie koncepcyjne, kreatywne działanie, doradzanie i mentorstwo, zarządzanie ludźmi i relacjami, kontrola nad przedsięwzięciem, wywieranie wpływu przez język przekazu i idee. Oczywiście zdarza się, że pracownik ma więcej niż jedno zamiłowanie.

- Ocenę osiągnięć w działalności zawodowej, której celem jest określenie zadań ekscytujących oraz tych, do których brak pracownikowi zapału. 
- Zmianę dotychczasowego zakresu zadań pracownika i dopasowanie go do jego zamiłowań, dzięki czemu jego praca staje się bardziej satysfakcjonująca.

Proponowane działania prowadzą do wielu przekształceń w organizacji i oddzielenia od zadań do wykonania przypisanych poszczególnym pracownikom tych, których nie lubią wykonywać. Oznacza to, że ktoś inny będzie musiał to robić. Przeważnie jednak znajduje się ktoś, komu pasuje zadanie nieodpowiadające innemu. A gdyby tak się nie stało, zawsze można tę kwestię negocjować z daną osobą. Uczciwe postawienie sprawy i traktowanie pracownika jak równego partnera umożliwia znalezienie rozwiązania satysfakcjonującego obie strony.

Zarysowane postępowanie nie jest jedynym sposobem pozwalającym budować zaangażowanie i lojalność zatrudnionej kadry i zmniejszającym prawdopodobieństwo wystąpienia niekorzystnych zjawisk w pracy takich jak stres, pracoholizm i wypalenie zawodowe. Zarówno praktycy, jak i teoretycy zarządzania oraz psychologowie i socjologowie nadal poszukują rozwiązań pozwalających stworzyć w organizacji miejsce pracy atrakcyjne dla pracowników, które umożliwi ich przyciągnięcie, utrzymanie i zapewni im zadowolenie z pracy. Celowi temu służą na przykład promowanie kultury zaufania w organizacji, koncepcje jakości życia czy równoważenia pracy i życia, społecznej odpowiedzialności organizacji, etyki w biznesie, jak również liczne modele dopasowania osoby i środowiska wykorzystywane w badaniach nad stresem. Podejmowane próby prowadzą do poprawy sytuacji w organizacjach je wykorzystujących. W każdym jednak przypadku osiągnięcie trwałego sukcesu wymaga zmiany w podejściu do pracownika i myśleniu o nim w kontekście strategicznym.

\section{Zakończenie}

Prowadzone rozważania wskazują, że współczesna organizacja musi myśleć strategicznie o pracowniku, jeśli chce przetrwać w zmiennym otoczeniu, rozwijać się i odnosić sukcesy. Jednak myślenie to nie powinno być nakierowane tylko na inwestycje w kompetencje pracownika, ale również w budowanie i utrzymanie jego energii pochodzącej z ciała, emocji, umysłu i ducha, będącej jego „zdolnością produkcyjną” (Schwartz, 2007, s. 72-83). Bez tej zdolności kompetentny pracownik nie będzie zaangażowany w pracy, w pełni wydajny, a to znajdzie odzwierciedlenie w osiąganym przez organizację wyniku finansowym. Traci pracownik, ale i organizacja. A może być zupełnie inaczej - obie strony osiągają sukces. Wymaga to jednak, by organizacja za swój cel obrała pracownika i zgodnie z tym podejściem określiła strategię swojego działania.

B i $\quad b \quad$ l $\quad$ i

Aitkenhead, R. (2012). Świat na sprzedaż. Forum, 27.

Buchholz, T. (2011). Rush: why you need and love the rat race. London: Penguin Books Ltd.

Butler, T., Waldroop, J. (2006). Modelowanie pracy jako sposób motywowania najlepszych ludzi. Harvard Business Review Polska, 41-42.
CBOS (2011). Stosunek Polaków do pracy i pracowitości. Warszawa: BS/38/2011.

Chrzanowska, A. (2012). Spaleni pracą - wywiad z Ch. Maslach. Psychologia Dziś, 1.

Dettmer, M., Shafy, S. i Tietz, J. (2011). Kiedy świeca się dopala. Forum, 6 . 
Drucker, P.F. (2006). Jak zarządzać samym sobą. Harvard Business Review Polska, 41-42.

Eisentat, R.A., Beer, M., Foote, N., Fredberg T. i Norrgren F. (2008) Bezkompromisowy lider. Harvard Business Review Polska, nr 65-66.

Fazlagić, J.A. (2008). Charakterystyka pokolenia Y. E-mentor, 3. Pozyskane z: http://www.e-mentor.edu.pl/artykul/index/ numer/25/id/549 (16.05.2012).

Fromm, E. (2011). Mieć czy być? Poznań: Dom Wydawniczy Rebis.

Grzybek, R. (2012). Generacja Y - wyzwania dla zarządzających, Personel PLUS, 3.

Gut, R. (2008). Zarzqdzanie sobq $w$ stresie. W: R. Gut, M. Piegowska i B. Wójcik, (red.), Zarzq̨dzanie sobq. Ksiq̨żka o działaniu, myśleniu i odczuwaniu. Warszawa: Wydawnictwo Difin.

Kaniewska, A. (2012). Wyścig szczęśliwych szczurów. Coaching, 1.

Kilinger B. (2007). Pracoholicy. Szkoła przetrwania. Poznań: Dom Wydawniczy Rebis.

Kim, W.Ch. i Mauborgne, R. (2006). Chcesz, by pracownicy dali z siebie wszystko? Graj fair! Harvard Business Review Polska, 41-42.

Kets de Vries, M.F.R. (2006). Niebezpieczeństwa niskiej samooceny: czy czujesz się jak oszust? Harvard Business Review Polska, nr 44.

Krawiec J. (2011). Przywódcy potrzebni od zaraz. Gazeta Wyborcza, 5 grudnia.

Król, H., i Ludwiczyński, A. (2006). Zarządzanie zasobami ludzkimi. Tworzenie kapitału ludzkiego organizacji. Warszawa: Wydawnictwo Naukowe PWN.

Majewska-Opiełka, I. (2003). Sukces firmy. Gdańsk: Gdańskie Wydawnictwo Psychologiczne.

Maslach, Ch. i Leiter, M.P. (2011). Prawda o wypaleniu zawodowym. Co robić ze stresem w organizacji. Warszawa: Wydawnictwo Naukowe PWN.

Merrill A.R. i Merrill, R. (2004). Mądre życie. Warszawa: Wydawnictwo Świat Książki.
Młodzi 2011 (2011). Raport. Warszawa: Kancelaria Prezesa Rady Ministrów.

OECD (2012). http://stats.oecd.org/ (16.08.2012).

Pierce, J.L. i Gardner, D.G. (2004). Self-Esteem Within the Work and Organizational Context: A Review of the Organization-Based Self-Esteem Literature. Journal of Management, 30(5), DOI: 10.1016/j.jm.2003.10.001.

Plażyk K. (2011). Dekonsumpcja, ekologizacja i zrównoważona konsumpcja jako przeciwwaga dla konsumpcjonizmu. Materiały Krakowskiej Konferencji Młodych Uczonych. Pozyskane z: http://www.profuturo.agh.edu.pl/pliki/Referaty_VI_KKMU/ NE/P_103_AGH-VI_KKMU.pdf (17.05.2012).

Reichheld F.F. (2008). Przywództwo prowadzące do lojalności. Harvard Business Review Polska, nr 63.

Ringer R.J. (1977). Looking Out for Number One. New York: Ballantine Books.

Rzeczpospolita (2009). Co dziesiaty menedżer pracuje na pól gwizdka. Pozykane z: http://www.extendeddisc.pl/ (1.03.2012).

Sasak T. (2004). Pracoholizm. Pozyskano z: www.controling. info.pl/artyk/pokaz_a_print.php3?nr=118 (16.05.2007).

Schaufeli, W.B., Enzmann, D.U. (1998). The Burnout Companion to Study and Practice: A Critical Analysis. London: Taylor\&Francis.

Schwartz, T. (2007). Zarządzaj swoją energią a nie czasem. Harvard Business Review Polska, 58.

Słownik języka polskiego (2012) Wydawnictwo Naukowe PWN. Pozyskano z: http://sjp.pwn.pl/szukaj/niewolnictwo (14.08.2012).

Veblen, T. (1971). Teoria klasy próżniaczej. Warszawa: PWN.

Waitley, D. (1996). Podwójne zwycięstwo. Warszawa: Oficyna Wydawnicza Logos.

Wojdyło, K. (2010). Pracoholizm. Perspektywa poznawcza. Warszawa: Wydawnictwo Difin.

Wojdyło, K. (2012). Mroczne pracy pożądanie. Charaktery, 3. Wrabec, P. (2009). Wypalenie zawodowe - jak pokonać hydrę zniechęcenia. Poradnik Psychologiczny Polityki, 3(4). 